\title{
Microclimatic analysis of mangroves in two distinct categories of Protected Areas and conserved status
}

\author{
Nádia Gilma Beserra de Lima ${ }^{1}$ \\ Marilia Cunha-Lignon ${ }^{2}$ \\ Emerson Galvani ${ }^{3}$
}

$\begin{array}{ll}\text { Keywords: } & \text { Abstract } \\ \text { Climatic attributes } & \text { Mangrove forests provide essential ecosystem services to human } \\ \text { Monitoring } & \text { communities, including climate regulation. In Brazil, the National } \\ \text { Microclimate } & \text { System of Nature Conservation Units divides Protected Areas (PAs) } \\ \text { Sustainable Use } & \text { into two categories: Full Protection (FP) and Sustainable Use (SU). The } \\ \text { Full Protection. } & \text { FP areas are composed of five categories, including National Parks, and } \\ & \text { the SU areas comprise seven categories, such as Environmental } \\ & \text { Protection Areas. The current research compared climatic attributes, } \\ & \text { leaf area index, and vegetation structure development in mangrove } \\ & \text { forests in two distinct categories of PAs (FP and SU) along the southern } \\ & \text { coast of the state of São Paulo (Brazil) to analyze the climatic conditions } \\ & \text { in different PA categories. A survey of the microclimatic attributes } \\ & \text { found that the conserved mangroves in the FP PA presented a) greater } \\ & \text { thermal stability in terms of the maximum, minimum, and mean air } \\ & \text { temperatures, and b) a better role of mangrove vegetation in } \\ & \text { (re)distributing the energy inside the forest. Therefore, it is affirmed } \\ & \text { that FP PAs play a fundamental role in maintaining the good } \\ \text { conservation status of mangroves and, consequently, stabilizing the } & \text { microclimate. }\end{array}$

\footnotetext{
${ }^{1}$ Instituto Geológico. São Paulo, SP, Brasil.nadiag@sp.gov.br

${ }^{2}$ Universidade Estadual Julio de Mesquita Filho - UNESP. Registro, SP, Brasil. cunha.lignon@unesp.br

${ }^{3}$ Universidade de São Paulo - USP. São Paulo, SP, Brasil. egalvani@usp.br
} 


\section{INTRODUCTION}

Mangroves are distributed in the intertidal zone in tropical and subtropical regions from approximately $30^{\circ} \mathrm{N}$ to $30^{\circ} \mathrm{S}$ latitudes. Large ocean currents and the $20^{\circ} \mathrm{C}$ isotherm of the surface water of the sea delimit their global distribution. Mangroves respond globally to latitudinal temperature gradients, and gradients of soil salinity are locally common. Therefore, understanding the ecophysiological responses of mangrove trees to environmental gradients is essential when considering the limited number of mangrove species that occur along these gradients. This knowledge is of critical importance to the conservation of this ecosystem (LUGO et al., 2014).

Mangrove ecosystems are among the most biologically productive and important in the world, providing ecosystem goods and services that are important and unique to society and coastal and marine systems. Mangroves are considered natural protectors of shorelines during storms, hurricanes, and tsunamis (ALONGI, 2008; LACAMBRA et al., 2008; KRAUSS et al., 2009; MCIVOR et al., 2012; ZHANG et al, 2012).

Climate change is likely to substantially impact mangrove ecosystems via processes that include sea-level rise, changing ocean currents, increased storminess, increased temperature, changes in precipitation, and increased $\mathrm{CO}_{2}$ (ELLISON, 2015).

Brazil has the third-largest mangrove area globally (GIRI et al., 2011), 962,683 ha, corresponding to $7 \%$ of the total global area. In Brazil, mangroves are protected under the federal Forest Law and are designated as permanent protection areas by the Forestry Code (MAGRIS; BARRETO, 2010). According to the authors, mangroves in Brazil have a high level of protection, with approximately $83 \%$ of their vegetation cover located within Protected Areas.

The National System of Conservation Units was established by Law 9,985 on July 19, 2000. Protected Areas (PAs) fall into two categories: Full Protection and Sustainable Use. Protected Areas of Full Protection have the main objective of conserving biodiversity, whereas various forms of natural resource use and the protection of biodiversity carried out secondarily are allowed in the Protected Areas of Sustainable Use (BRASIL, 2000).

Seventy-seven percent of the mangroves in Brazil are under protection as PAs of Sustainable Use (MAGRIS; BARRETO, 2010).
However, mangroves have presented significant changes originating from anthropic influence on the environment, mainly those located in PAs of Sustainable Use such as Environmental Protection Areas (VALIELA et al., 2001). As a result, mangrove areas are becoming smaller or fragmented (or even both), which causes loss of ecosystem services and benefits over time (DUKE et al., 2007).

Mangrove microclimates have been studied to indicate what changes occur in the mangrove structure, at its edge, and within its ecosystem. In addition, the study of the microclimatic variables can contribute to the understanding of the importance of mangroves in the event of storms and extreme events at a local scale (LIMA et al., 2013; BESERRA DE LIMA; GALVANI, 2013).

The main aim of this study was to compare mangroves in PAs with different degrees of protection, in the Cardoso Island Park (Full Protection - FP) and Environmental Protection Area of Cananeia-Iguape-Peruíbe (Sustainable Use - SU), considering climatic conditions. This research analyzed the following climatic elements: air temperature, global solar radiation, precipitation, direction and wind speed, the leaf area index (LAI) and vegetation structure development.

\section{MATERIALS AND METHODS}

\section{Study Area}

The Cananeia-Iguape Coastal System (CICS) consists of a complex of lagoon channels and is part of the UNESCO World Heritage site "Atlantic Forest South-East Reserves" established in 1999. The CICS mangrove area is considered the most important mangrove area of São Paulo State due to its extension and conservation stage. Its extent estimation is of 15,193 ha (CUNHA-LIGNON et al., 2011).

Despite the region's conservation, studies have identified clearings in mangrove areas in the Iguape region due to the increase in invasive aquatic macrophytes in this sector that resulted from the opening of the Valo Grande canal (CUNHA-LIGNON et al., 2011). The opening of this canal occurred between 1827 and 1852 and caused significant changes in salinity and sedimentation patterns, and on the contribution of heavy metals to the CICS (MAHIQUES et al., 2009). Figure 1 shows the distribution of mangroves and macrophytes in the CICS.

The Environmental Protection Area of Cananeia-Iguape-Peruíbe was created by 
Decree $\mathrm{n}^{\circ}$ 90,347/1984 (BRASIL, 1984) and extended by Decree ${ }^{\circ}$ 91,892/1985 (BRASIL, 1985). It is a Federal PAs of Sustainable Use (SU). Cardoso Island State Park, a category under Full Protection (FP), was created in 1962 by State Decree No. 40,319 (SÃO PAULO, 1962). This park is under the care of the Environmental Office of São Paulo State.

Figure 1 - Distribution of mangroves in the Cananeia-Iguape Coastal System, location of the Automatic Meteorological Stations and the Cananeia-Iguape-Peruíbe Environmental Protection Area (SU), and the Cardoso Island State Park (FP).

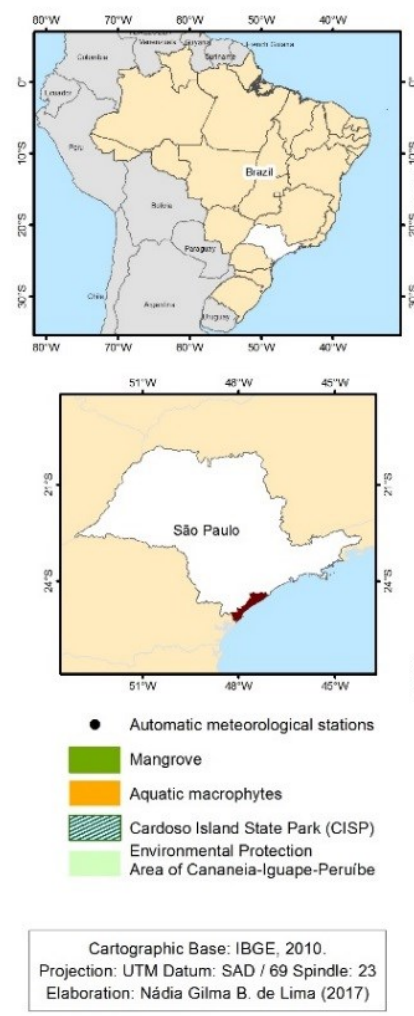
Elaboration: Nádia Gilma B. de Lima (2017)
Elojection:

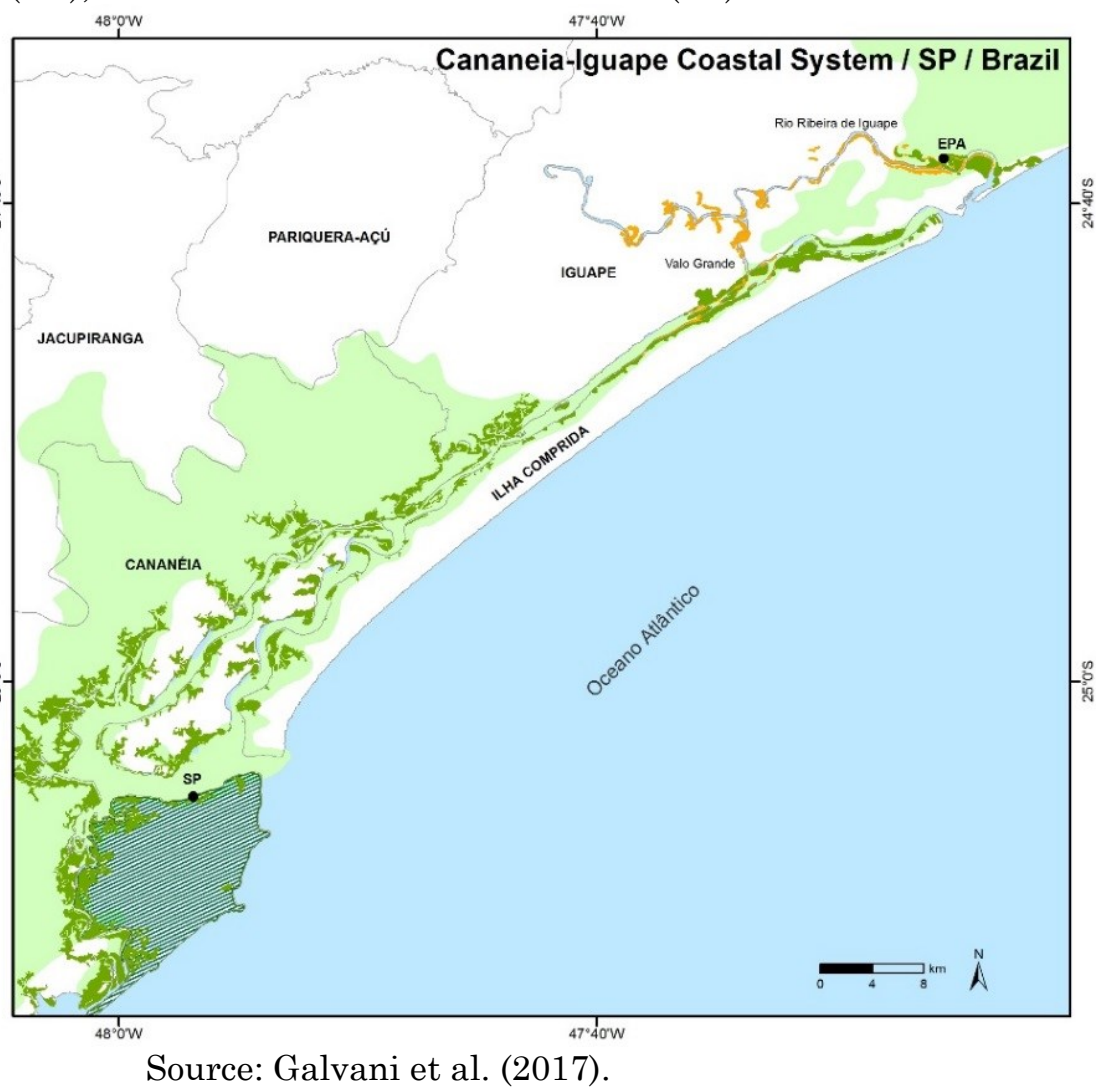

\section{Methodology}

The characterization of the development of the forest structure followed the methodology suggested by Schaeffer-Novelli et al. (2015). The mangrove forest's vegetation structures were described and monitored in July or August 2012, 2013, 2014, and 2015. We established a $13 \mathrm{~m} \times 13 \mathrm{~m}$ permanent plot in the area Sustainable Use (SU) and a $10 \mathrm{~m} \times 5$ $\mathrm{m}$ permanent plot in the Full Protection (FP) area, based on the stem density of each mangrove area. According to methodology, each plot included about 30 mangrove tree individuals. Both sites have a similar tidal flooding frequency. We identified all plants in each plot and recorded the tree diameter, height, and occurrence of associated species. In each plot, individuals with height $\geq 1 \mathrm{~m}$ will be identified according to species, living or dead condition, and will have their total height measured by a manual telemeter or a Bosch GR 500 ruler, according to tree height, depending on the lower limit of the telemeter. We measured the diameter at breast height $(\mathrm{DBH}=1.30 \mathrm{~m}$ above ground level $)$ of each trunk with a Forest Suppliers Steel diameter tape graduated in pi (п) and calculated the mean height, basal area dominance, and stem density. We estimated the basal area of the forest from diameter measurements $(<2.5 \mathrm{~cm}$; $2.5 \mathrm{~cm}-10.0 \mathrm{~cm} ; \geq 10.0 \mathrm{~cm})$ within a hectare.

We started a microclimatic survey in the northern sector of the CICS, part of the Environmental Protection Area of CananeiaIguape-Peruíbe (SU category). Monitoring began with installing a microclimatic tower containing two automatic meteorological stations (AMSs), which analyzed the vertical variation of the climatic attributes and the influence of the mangrove canopy on the microclimate. The microclimatic tower had a meteorological station at the height of $2 \mathrm{~m}$, with sensors for air temperature, relative air humidity, wind direction and speed, precipitation, and global solar radiation. 
Another meteorological station was installed above the vegetation canopy at $12 \mathrm{~m}$ to obtain the same climatic attributes plus a radiometer balance. The equipment was programmed to register every 10 minutes. The installation of an AMS happened in 2011 at the southern sector of Cardoso Island State Park (FP category). The station was $2 \mathrm{~m}$ above ground and contained air temperature, relative air humidity, wind direction and speed, global solar radiation, and rainfall sensors. The analysis periods for each attribute differed due to technical failures of some equipment over the monitoring period, as shown in Table 1.

Table 1 - Period of analysis of climatic attributes recorded in the Cardoso Island State Park mangroves and the Environmental Protection Area of Cananeia-Iguape-Peruíbe.

\begin{tabular}{cc}
\hline Climate Attributes & Period \\
\hline Air temperature & October 1st 2011 to April 30th 2015 \\
Solar radiation & October 1st 2011 to May 29th 2013 \\
Wind speed & October 1st 2011 to December 13th 2013 \\
Precipitation & October 1st 2011 to November 31th 2012 \\
Atmospheric Systems & May 29th to June 12th 2012 \\
\hline
\end{tabular}

Org.: by the Authors.

For data analysis, descriptive statistics, the Anderson-Darling test were used to identify the normality of the variables, and the nonparametric Wilcoxon hypothesis test.

We designed the comparison between the Full Protection (FP) and Sustainable Use (SU) forests according to the following premises:

- The regional climate in both mangrove forests can be considered uniform within the boundaries of the study area.

- The AMS installed in the SU category did not experience a significant influence of continental effects, even $4.3 \mathrm{~km}$ from the coastline.

- The AMS installed in the FP category mangrove near the border, which was in the leeward conditions of Cardoso Island, also did not experience a rain shadow effect from the relief of the study area.

In this study, we obtained hemispheric photographs in the SU and FP areas in the two mangrove forests. These photographs were obtained using a NIKON Model F-501 camera with an 8-mm NIKOR fisheye lens and a $180^{\circ}$ aiming angle, known as a 'fisheye lens.' We processed the photographs in the Gap Light
Analyzer software - GLA version 2 (free software). However, although the LAI in its definition is related only to leaf area, the GLA software does not make this differentiation but does consider branches, flowers, and fruits in its analysis.

\section{RESULTS AND DISCUSSION}

\section{Mangrove Structure Vegetation}

The typical mangrove plant species Rhizophora mangle (red mangrove) dominates in the mangrove forests of the SU category and FP category, with $100 \%$ and $86.4 \%$ dominance in basal area, respectively. The two studied areas presented similar plant structures in $\mathrm{DBH}$, mean height, and relative densities of live trunks. However, the absolute density was quite different, with 8,400 trunks/ha in the mangrove forest in the FP area and 2,071 trunks/ha in the SU mangrove forest (Table 2 and Figure 2).

Table 2 - Vegetation structure of mangrove forests studied in areas under different degrees of protection: Full Protection and Sustainable Use. Rh: Rhizophora mangle, Lg: Laguncularia racemosa. DBH: diameter at breast height.

\begin{tabular}{ccc}
\hline Structure Data & Full Protection (FP) & Sustainable Use (SU) \\
\hline DBH $(\mathrm{cm})$ & $5.11 \mathrm{~cm}$ & $7.37 \mathrm{~cm}$ \\
\hline Average height $(\mathrm{m})$ & $8.45 \mathrm{~m}$ & $11.46 \mathrm{~m}$ \\
\hline & $45.24 \%(\mathrm{Rh}) \mathrm{DBH}<2.5 \mathrm{~cm}$ & $5.71 \%(\mathrm{Rh}) \mathrm{DBH}<2.5 \mathrm{~cm}$ \\
Relative density of & $7.14 \%(\mathrm{Rh}) 2.5 \mathrm{~cm}<\mathrm{DBH}<10.0 \mathrm{~cm}$ & $14.29 \%(\mathrm{Rh}) 17.14(\mathrm{Lg}) 2.5$ \\
live trunks $(\%)$ & $23.81 \%(\mathrm{Rh}) \mathrm{DBH}>10.0 \mathrm{~cm}$ & $\mathrm{~cm}<\mathrm{DBH}<10.0 \mathrm{~cm}$ \\
& Total: $76.19 \%$ & $40.00 \%(\mathrm{Rh}) \mathrm{DBH}>10.00 \mathrm{~cm}$ \\
& & Total: $77.14 \%$ \\
\hline $\begin{array}{c}\text { Absolute Density } \\
\text { (trunks / ha) }\end{array}$ & 8.400 trunks/ha & 2.071 trunks/ha \\
\hline
\end{tabular}

Org.: by the Authors. 
Figure 2 - The mangroves' external and internal views studied areas in the Sustainable Use category (A and B) and Full Protection category (C and D), respectively. Photos obtained in July 2015 (in the FP) and September 2015 (in the SU).
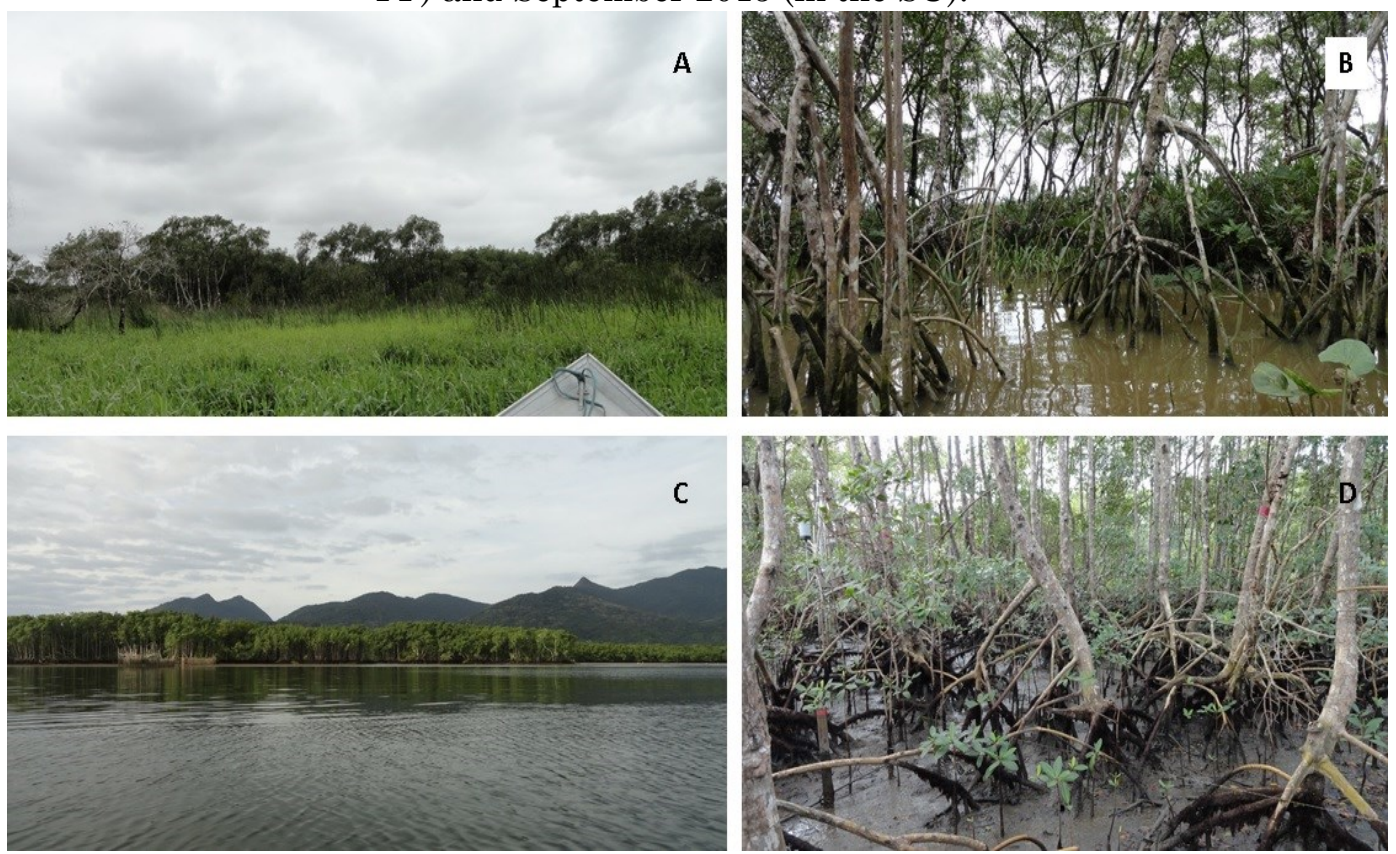

Source: The Authors.

There are associated species in the mangrove forest in the SU category, such as Acrostichum aureum L. (mangrove fern) and aquatic macrophytes (such as Urochloa arrecta, Paspalum repens, Crinum americanum, and Cyperus sp.), that indicate changes in the environment (Figure 2). In Cardoso Island State Park (FP), the forest is characterized by recruitment of seedlings and young individuals, confirmed with the high values of relative density of live trunks with $\mathrm{DBH}<2.5 \mathrm{~cm}$, whereas there is low recruitment of seedlings in the SU (Table II and Figure 2). Thus, there are records of mangrove forests in their initial state that respond positively to the depositional process near FP (CUNHA-LIGNON et al., 2011).

\section{Leaf Area Index (LAI)}

Leaf area is an important structural feature for any type of vegetation because it is in the canopy that fundamental processes for the ecosystem occur, such as transpiration, rainfall interception, photosynthesis, and providing organic matter for litter. Therefore, the LAI definition was the integrated leaf area of the canopy per unit area projected in the soil $\left(\mathrm{m}^{2} / \mathrm{m}^{2}\right)$, computed when considering the surface of only one side of the leaves (WATSON, 1974).

The FP forest had the largest LAI throughout the year. The lowest value recorded in the two forests occurred during the winter in August 2011; LAI was 1.12 in the category forest and 1.27 in the FP forest (Figure 3). The higher records were in December 2012 (2.52) and April 2012 (1.71) for the FP forest and the SU categories. In the forest of the FP category, the difference between the lowest (1.27) and the highest (2.52) LAI corresponded to approximately $98.4 \%$. Additionally, mangroves in the SU category exhibited an increase of $52.7 \%$ from August 2011 (1.12 - lower LAI) to April 2012 (1.71 - higher LAI).

For the SU forest, it was possible to compare the estimated value of LAI in the two representative months of winter: August 2011 had an LAI (1.12) lower than in July 2012 (1.58). The total precipitation can explain this event for the months of June, July, and August in the two years analyzed. In 2011, the total precipitation in these months was lower than the same months in 2012, maybe contributing to a more significant number of leaves present in the mangrove in the last year. While in June, July, and August 2011, there were 398.8 $\mathrm{mm}$, in 2012 , the total was $568.4 \mathrm{~mm}$.

During the rainy season (spring/summer), there was a significant increase in leaf production, which favored the formation of new leaves; this production decreased in the less rainy season. 
Figure 3 - Variation of leaf area index estimated by hemispheric photographs in SU and FP mangrove forests.

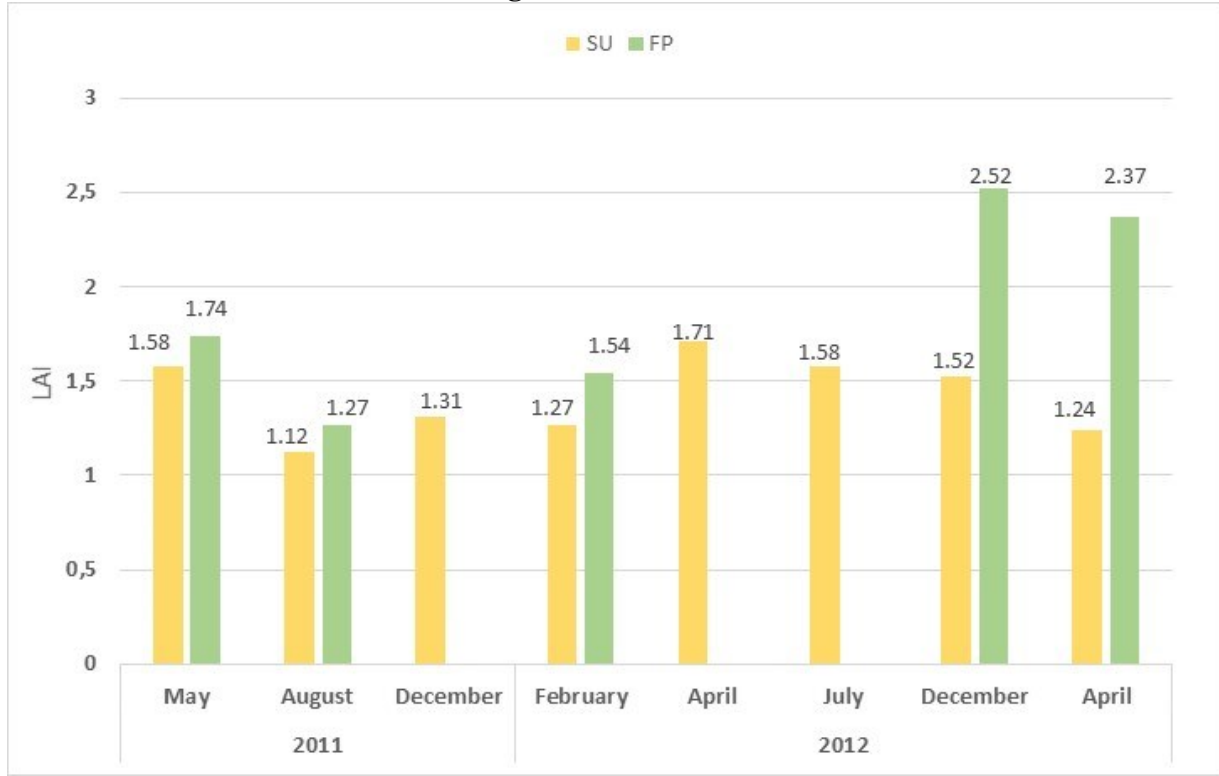

Source: The Authors.

LAI values have ranged from $0.2 \mathrm{~m}^{2} / \mathrm{m}^{2}$ in scrub forests to $5.1 \mathrm{~m}^{2} / \mathrm{m}^{2}$ in riverine forests with more significant structural development in mangroves. However, this value is considered reduced compared with the tropical forest that would present values between 8 and $10 \mathrm{~m}^{2} / \mathrm{m}^{2}$, attributed to the fact that the species do not tolerate shading (CINTRÓN; SCHAEFFER-NOVELLI, 1983).

A study of litter production in mangroves in the Caribbean region highlighted a marked seasonality of litter production rates during the wetter period (summer) and a decrease in winter (POOL et al., 1975). The LAI results from the interaction of precipitation from the preceding period and the solar radiation available in the environment (POOL et al., 1975; LUGO; SNEDAKER, 1975).

Considering the precipitation and the LAI observed in the SU category mangrove, we identified a relationship between the additions/reductions of the LAI and the monthly distribution of rainfall, with higher leaf production during spring/summer, which is the rainy season in the area of study. This LAI response to precipitation was more noticeable when compared to the regular climatological monthly precipitation, and less evident when the precipitation was evaluated in the studied years. However, this relationship was not linear; thus, other controls of the LAI in addition to precipitation were at play.

\section{Microclimate}

\section{Air Temperature}

Table III shows the synthesis of air temperature values and its derivatives, where it is possible to notice that the values accompany the solar declination independently of the variable (maximum, average, or minimum).

The highest absolute recorded temperature occurred in December 2012 , with $39.1^{\circ} \mathrm{C}$ in the mangrove located in the SU category and $36.6^{\circ} \mathrm{C}$ in the FP category (Table 3 ).

Table 3 - Synthesis of the maximum (Tmax), minimum (Tmin), and average (Tmed) values and thermal amplitudes in the two mangrove forests: Sustainable Use and Full Protection.

\begin{tabular}{c|ccc|cc|c}
\hline $\begin{array}{c}\text { Protected } \\
\text { Areas }\end{array}$ & \multicolumn{3}{|c|}{ Medium values $\left({ }^{\circ} \mathbf{C}\right)$} & \multicolumn{2}{c|}{$\begin{array}{c}\text { Absolute values } \\
\left({ }^{\circ} \mathbf{C}\right)\end{array}$} & $\begin{array}{c}\text { Thermal } \\
\text { Amplitude } \\
\left({ }^{\circ} \mathbf{C}\right)\end{array}$ \\
\hline Sustainable Use & 26.5 & 18.7 & 22.1 & 39.1 & 7.2 & 31.9 \\
Full Protection & 25.8 & 19.5 & 22.4 & 36.6 & 6.7 & 29.9 \\
\hline Deviation $\left({ }^{\circ} \mathrm{C}\right)^{*}$ & 0,7 & $-0,8$ & $-0,3$ & 2,5 & 0,5 & 2,0 \\
\hline
\end{tabular}

(*) Difference between values of Full Protection and Sustainable Use areas. Source: The Authors. 
This difference between the two mangrove forests was associated with the canopy structure, which was denser in the FP forest and prevented some energy from entering the system. Another month that deserves special mention is September 2012, which had the most significant difference in absolute maximum daily between the forests $\left(7.2^{\circ} \mathrm{C}\right)$, and the value was more significant in the mangroves in the SU. The lowest recorded value was in July $2013: 7.2^{\circ} \mathrm{C}$ in the $\mathrm{SU}$ mangroves and $6.7^{\circ} \mathrm{C}$ in the $\mathrm{FP}$ mangroves, a difference of 0.5. For the minimum temperature, the largest difference found between the two forests was $4.2^{\circ} \mathrm{C}$, although the minimum temperature in the FP forest was higher than that in the SU forest.

Considering the average temperature, the largest difference between the two locations occurred on March 23, 2014, with a positive difference of $2,3^{\circ} \mathrm{C}$. However, this difference was $-2.8^{\circ} \mathrm{C}$ on April 30, 2015; namely, the FP forest temperature was higher than that of the SU (Figure 4).

Figure 4 - Daily variation of average air temperature from October 1, 2011, to February 27, 2015, in the mangrove located in the SU and FP.

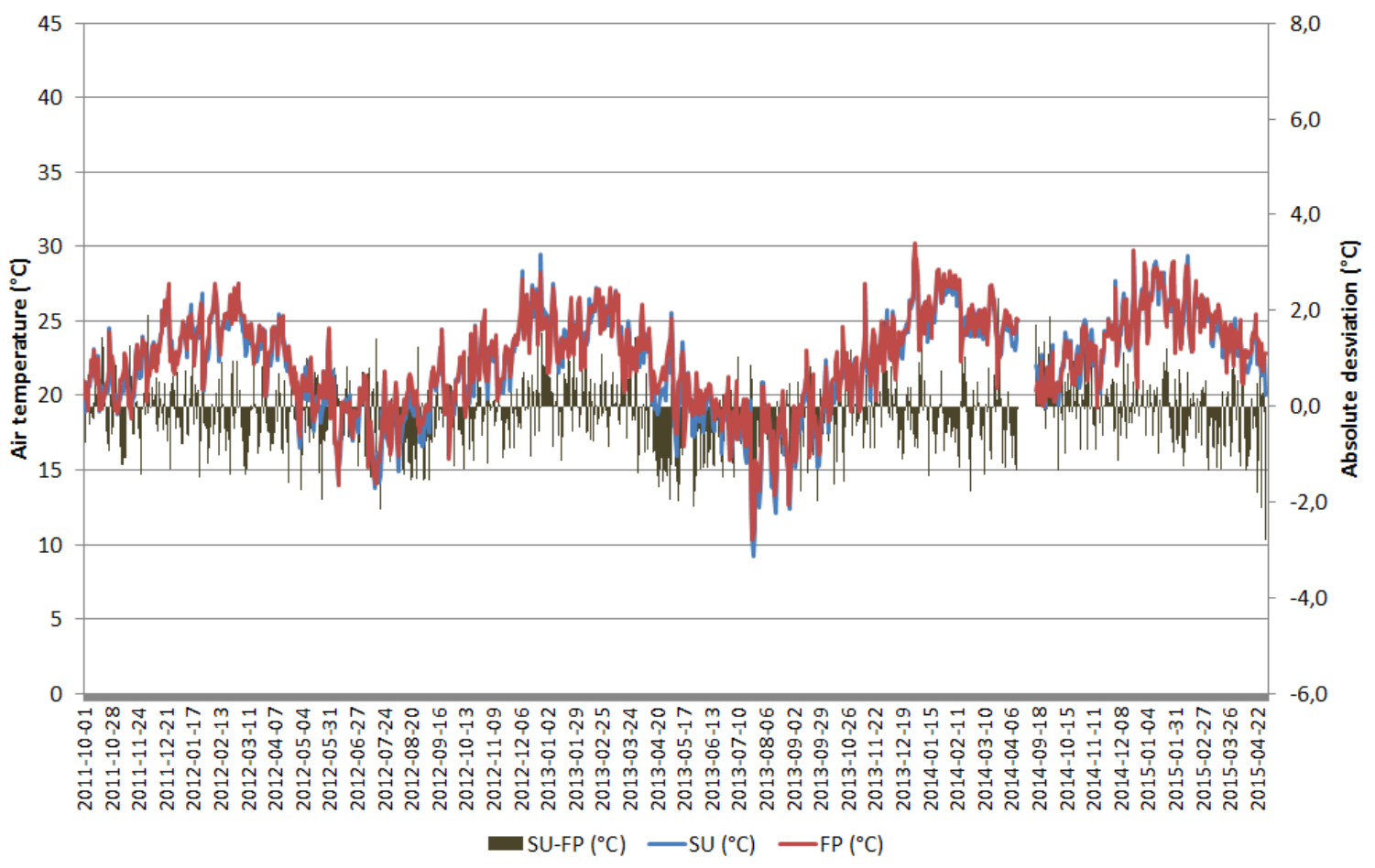

Source: The Authors.

The mean daily values mask variations at smaller time scales. For example, the differences occasionally reached $11.3^{\circ} \mathrm{C}$ in the hourly average temperature variation, where the SU mangrove temperature was higher than the FP mangroves. However, at another time, this difference was $-8.4^{\circ} \mathrm{C}$, i.e., the $\mathrm{FP}$ mangrove temperature was higher than the SU mangroves.

When considering the absolute maximums, the mangroves located in the SU (Figure 5) recorded the most extreme values. 
Figure 5 - Daily variation of the absolute maximum air temperature for the period from October 1 , 2011, to February 27, 2015, in the mangrove located in the SU and FP.



We also observed higher values in the FP minimums, with a difference between the two mangroves when considering the absolute forests from $-4.2^{\circ} \mathrm{C}$ to $2.9^{\circ} \mathrm{C}$ (Figure 6).

Figure 6 - Daily variation of the absolute minimum air temperature for the period from October 1, 2011, to February 27, 2015, in the mangrove located in the SU and FP.

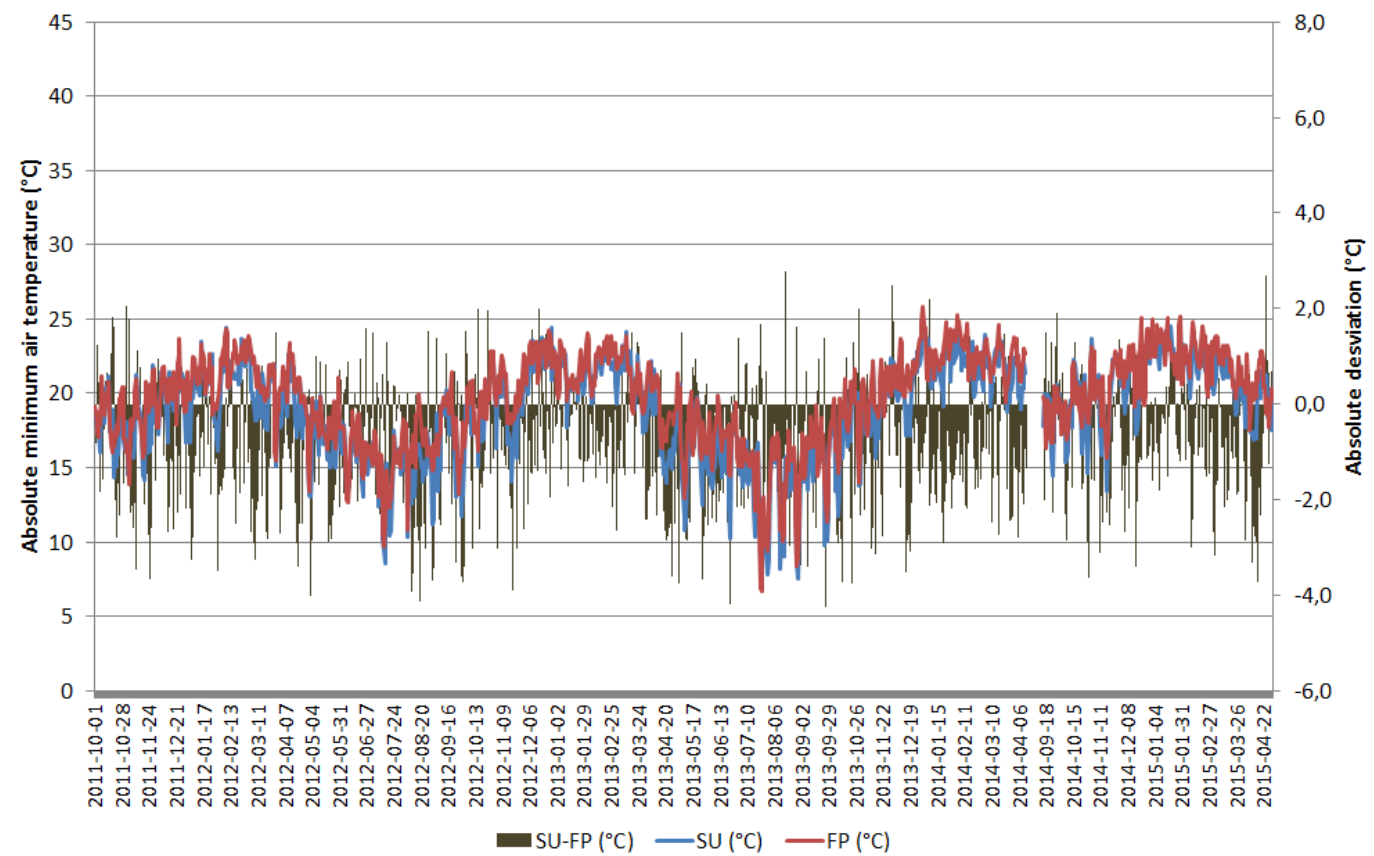

Source: The Authors.

The results indicate that the amplitudes were smaller in the FP forest, with lower variation in air temperature (Figure 7). The SU forest presented lower minimum temperatures and higher maximum temperatures. During the day, the open canopy allows more energy to reach and warm the mangrove substrate. At night, open canopies with less density facilitate greater energy loss to the atmosphere, enhancing greater thermal amplitudes and lower minimum air temperatures. 
Figure 7 - Daily thermal amplitude in forests located in SU and FP.



Source: The Authors.

\section{Global Solar Radiation}

The average daily global solar radiation in the

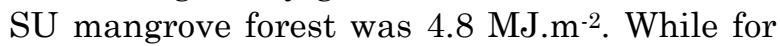

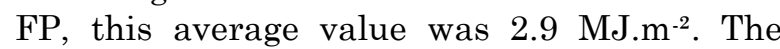
maximum daily global solar radiation in the SU was on $01 / 07 / 2013$, with $11.3 \mathrm{MJ} \cdot \mathrm{m}^{-2}$, in the FP was on 10/31/2012, with 6.5 MJ.m-2. Finally, the minimum daily of global solar radiation occurred in the SU on $07 / 07 / 2012$, with 0.32

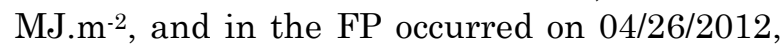
with only $0.2 \mathrm{MJ} . \mathrm{m}^{-2}$.

When comparing the two mangrove forests, we verified that the values in the FP forest located were lower than those in the SU forest. In figure 8, it was possible to observe a seasonal cycle related to the level of energy received at this latitude. Temperatures reached their highest values in the months of the year when the Sun declined to the Southern Hemisphere (September to March), whereas we observed lower values of air temperature in the months in which the Sun had positive declension (northern hemisphere between the months of April to August). This finding demonstrates that the microclimate experienced by these environments is conditioned to larger-scale controls, such as latitude and solar declination. Moreover, we verified that the amplitude of the global solar radiation in the period was larger in the $\mathrm{SU}$ mangrove forest. The amplitude in the FP


MJ.m-2 in the SU forest. 
Figure 8 - Global solar radiation at 2 meters in the area of the SU and FP, from October 10, 2011, to May 29, 2013.



Source: The Authors.

In the summer, it was possible to observe a higher incidence of solar radiation within the SU forest than in other seasons of the year. In the FP mangrove forest of Cardoso Island, a smaller variation occurred in the amount of incident solar radiation between summer and winter, although this variation was noticeable. The FP mangrove forest in Cardoso Island was less subject to variations in air temperature.

There was also greater variability in the data in the SU mangroves (Figure 9).

Figure 9 - Distribution of global solar radiation data in SU and FP mangroves from October 01, 2011, to May 29, 2013.

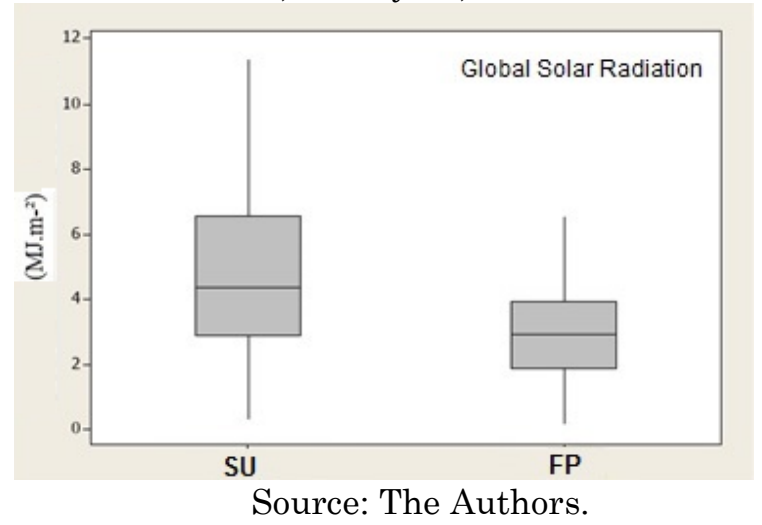

We applied a normality Anderson-Darling test to determine if the data obtained in the two forests presented significant differences. With the application of the test, we found that the daily data did not present a normal distribution $(p<0.005)$, which implied the application of the Wilcoxon hypothesis test at a $5 \%$ level of significance. In this case, we verified that the global solar radiation data obtained in the SU and FP mangrove forests were significantly different.

\section{Rainfall}

From October 10, 2011, to November 31, 2012, the sensor installed in the mangrove in the SU registered $1,994.3 \mathrm{~mm}$ of precipitation, whereas $1,717.9 \mathrm{~mm}$ was observed in the FP mangrove (Figure 10). Moreover, the month of June exhibited the largest precipitation in the SU forest $(356.8 \mathrm{~mm})$, which reflected an atypical year because January is considered the rainiest in the region, according to Tarifa (2004). In the FP mangrove, the highest accumulated rainfall occurred in January 2012 (248.8 mm). 
Figure 10 - Monthly precipitation recorded in the SU and FP mangrove forests.



Source: The Authors.

For the maximum daily precipitation, the SU mangrove forest registered $100 \mathrm{~mm}$ on December 25, 2011, whereas the FP mangrove forest had maximum precipitation over 24 hours of $155.0 \mathrm{~mm}$ on March 15, 2012. This difference in the daily totals and dates of occurrence was associated with the genesis of precipitation in the region during this time of year, typically characterized by localized convective processes of short duration and high intensity. We noticed, using a scatterplot, that the precipitation for the two forests deviated from linearity. It happened mainly in the period from March 15, 2012, to June 07, 2012, when the data deviate considerably from the trendline (Figure 11) and the rainfall in the FP forest was higher than in the SU.

Figure 11 - Simple linear regression of daily accumulated rainfall in SU and FP mangroves, respectively.

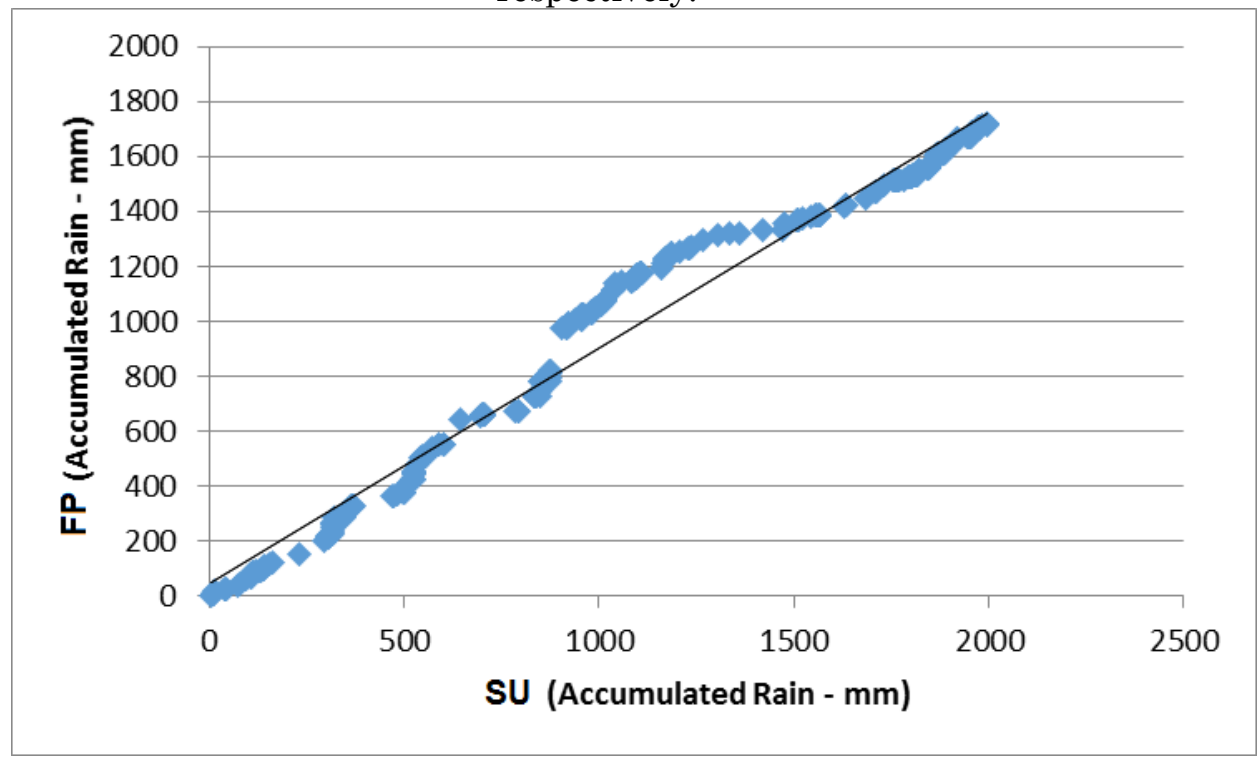

Source: The Authors. 


\section{Wind}

On the monthly scale, the FP mangrove forest recorded a higher wind speed than the SU forest. In terms of seasonal variations, both forests presented similar patterns. In the winter months, there was a notable decrease in wind speed.

In the vertical profile of the SU category mangrove (i.e., above and below the mangrove canopy), the mean wind speed in V12 was 0.6 $\mathrm{ms}^{-1}$, whereas it was $0.14 \mathrm{~ms}^{-1}$ in V2, corresponding to a reduction of $75.6 \%$. In the historical series, $67 \%$ of the period (411 days) presented a reduction in V2 above $70 \%$. Moreover, we observed a decrease in the maximum bursts' attenuation (Figure 12); there were no days when the reduction of bursts at 2 meters exceeded $80 \%$. These results demonstrate the critical contribution of mangroves to the environment.

Figure 12 - Attenuation of the mean velocity (red) and maximum wind (blue) gust by the SU mangrove canopy from $01 / 01 / 2012$ to $12 / 13 / 2013$.



Source: The Authors.

\section{Atmospheric system}

Specific meteorological systems were analyzed to present the interactions that occur within mangroves in greater detail.

The first period analyzed was May 29, 2012 to June 12, 2012, marked by the passage of a frontal system over the study area. This region of São Paulo state is characterized by the highest penetration rate of polar masses and frontal passages, according to Monteiro (1973).

At the beginning of June 2012, the seventh frontal system of May was still on the coast of São Paulo with low intensity; however, this system ushered in cold air that caused frost in the south of the country. At dawn on June 03, 2012, a cold front moved quickly to the south and west of Rio Grande do Sul state and advanced to the coast of Paraná state on June 04, 2012. On June 05, 2012, the cold front moved to the coast of São Paulo state. On June 10, 2012, a postfrontal high-pressure system acquired a maritime characteristic, which was short-lived in southeastern and southern Brazil.

However, the passage of a trough of low pressure between the south and São Paulo caused isolated storms between Paraná and part of the southern coast and east of São Paulo on June 11, 2012 (CPTEC, 2012).

From June 01, 2012, there was a significant reduction in the air temperature in the SU compared with the maximum value obtained on May 30,2012 , of $31.3^{\circ} \mathrm{C}$. The soil temperature reached values higher than $20^{\circ} \mathrm{C}$. From June 04 to June 11, 2012, the soil temperature was higher than the air temperature (Figure 13). Furthermore, we also observed tides, noticeable by the rhythm of rising and falling soil temperatures throughout the period. 
Figure 13 - Climatic attributes variation for the period from May 29 to June 12, 2012, in the SU mangrove forest

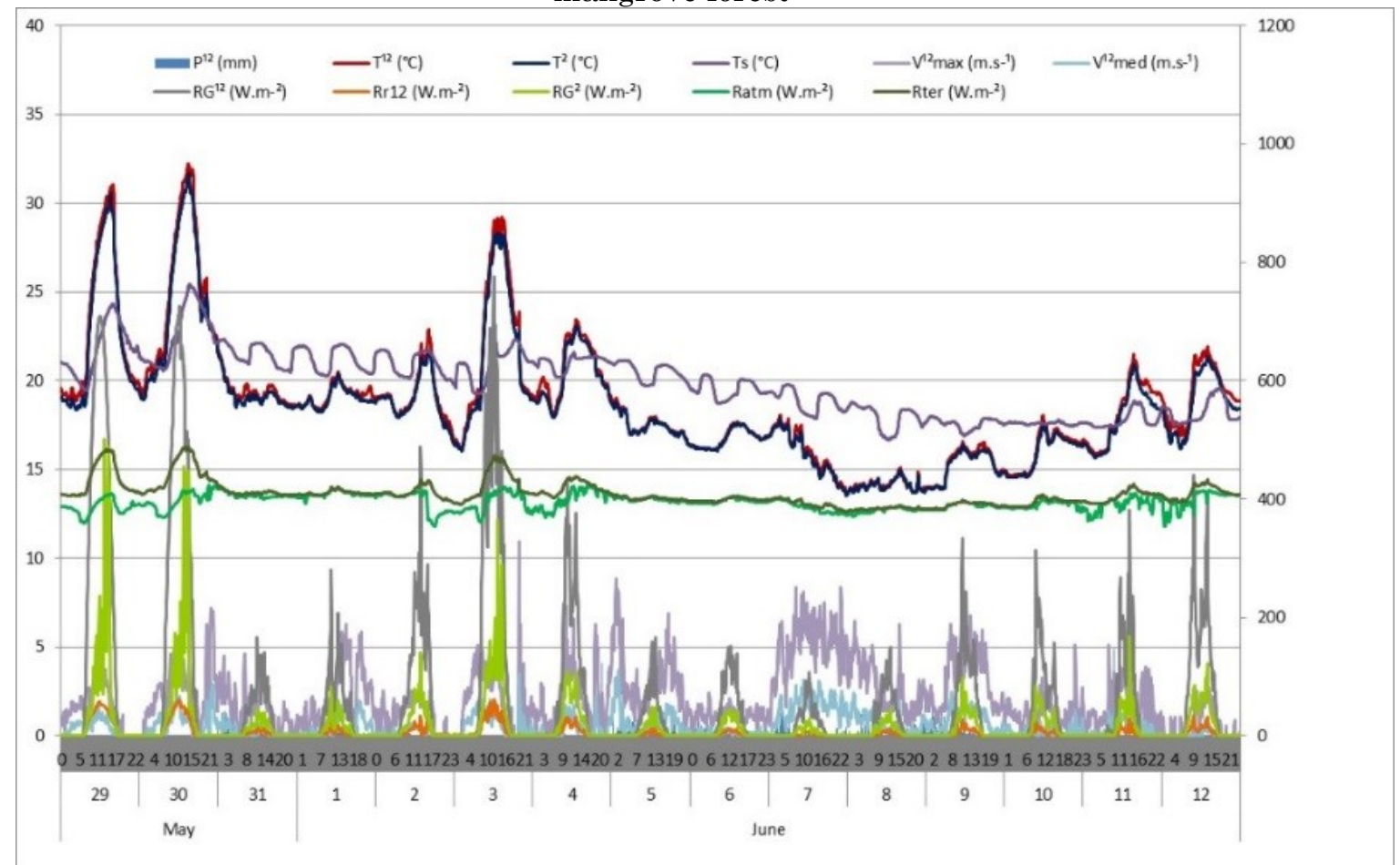

Source: The Authors. .Note: Air temperature at 12 meters (T12), air temperature at 2 meters (T2); soil temperature (Ts), rainfall (P12), average wind speed at 12 meters (V12med), maximum wind speed at 12 meters (V12max), global solar radiation at 12 meters (RG12), solar radiation reflected at

12 meters ( $\operatorname{Rr} 12)$, global solar radiation at 2 meters (RG2), terrestrial radiation (Rter) and atmospheric radiation (Ratm).

During this period in the SU, total precipitation recorded above the forest canopy was $266.7 \mathrm{~mm}$, whereas $321.7 \mathrm{~mm}$ recorded within the environment, which shows a negative intercept. In the FP forest, there was $118.6 \mathrm{~mm}$ of precipitation during the period considered.

In the SU forest, the highest shortwave solar radiation occurred on May 29, 2012 (16.4 MJ.m ${ }^{-2}$ ), whereas we recorded the smallest on June 07, 2012 (1.4 MJ.m ${ }^{-2}$ ). Below the SU forest canopy, these values were $4.2 \mathrm{~W} \cdot \mathrm{m}^{-2}$ and 0.4 MJ.m ${ }^{-2}$, respectively. However, in the FP forest, the maximum value was $3.3 \mathrm{MJ} . \mathrm{m}^{-2}$, and the


indicating greater protection in this environment against global solar radiation.

For terrestrial radiation (Figure 14), only measured in the SU forest, the lowest value occurred on June 08, 2012, related to cloudiness. The highest emission occurred on May 30, 2012, with an atmospheric transmissivity of $69.2 \%$. Atmospheric radiation was higher on May 31 and June 01, 2012, and the lowest value on June 08, 2012. During clear skies, the difference between territorial radiation (Rter) and atmospheric radiation (Ratm) reached more than 70 W.m. ${ }^{2}$. Moreover, the variations in the soil temperature in the mangrove forest of the sustainable use category follow the tides, and the variations are often the opposite of the air temperature variations (Figure 15).

During the approach of a front, the tropical air circulation presented an increase in the average daily air temperature due to the effect of circulation and the horizontal pressure gradient, as occurred on May 30, 2012. After the frontal passage, we observed a decrease in the air temperature over subsequent days due to an incoming polar air mass. However, the soil temperature sometimes increased, with a difference between the two sensors (air and soil) of up to $10^{\circ} \mathrm{C}$. During the night, the air temperature decreased while soil temperature increased, indicating the role of tides. At this scale of analysis, we can conclude that the tides control the variations in soil temperature in the mangroves, with the influence superimposed on the response to the incident solar radiation. 
Figure 14 - Terrestrial (Rter) and atmospheric radiations (Ratm), May 29 to June 12, 2012, Sustainable Use mangrove.

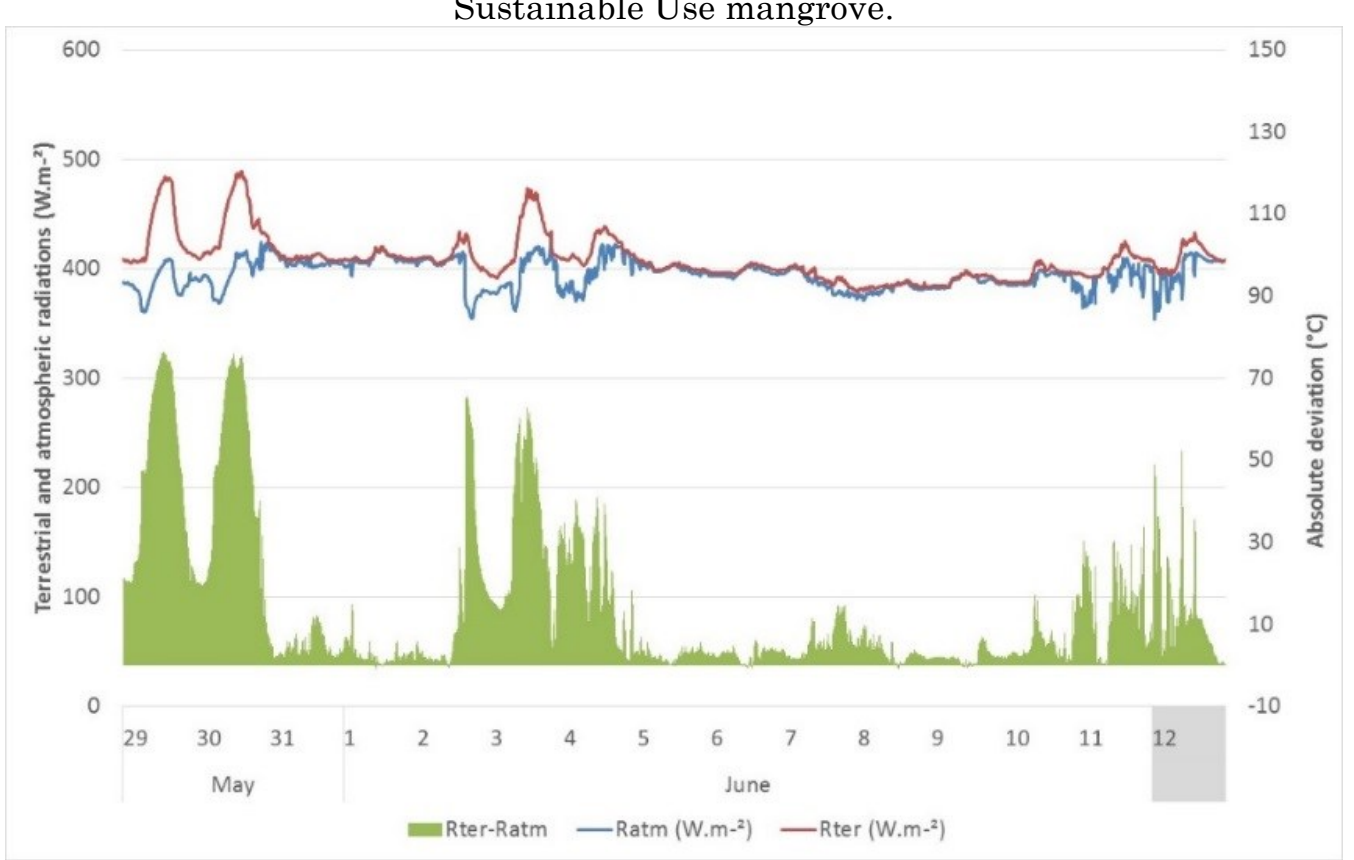

Source: The Authors.

Figure 15 - Variation of air and soil temperature in SU mangrove and air temperature in the FP mangrove, May 29 to June 12, 2012.



Source: The Authors.

\section{FINAL CONSIDERATIONS}

Considering how mangrove ecosystems intensively respond to environmental alterations, monitoring mangrove microclimate helps to understand the environmental conditions of distinct management categories in coastal PAs.

From a survey of the microclimatic attributes of mangroves during the monitored period, the conserved mangrove forest of Cardoso Island (Full Protection category) exhibits several essential characteristics: a) there is greater thermal stability in terms of maximum, minimum, and mean air temperatures and thus in the thermal amplitude; b) the role of mangrove vegetation is observable in the (re)distribution of energy inside the canopy when global solar radiation 
in mangrove forests is preserved (Full Protection) and altered (Sustainable Use), and c) mangroves may play an important role in interacting with extreme events, which reduces their effects.

In this way, it can be affirmed that Full Protection PAs play a fundamental role in maintaining the good conservation status of the mangroves of the southern coast of São Paulo state and, consequently, of their ecosystem services related to the stabilization of the microclimate, as those listed above. Ensuring the effectiveness of their management and monitoring actions is fundamental for the ecosystems located in the PAs. However, the sustainable use PAs have other categories that can maintain ecosystem services in a good way. The current paper does not intend to generalize the fragility of all Sustainable Use PAs but presents a concrete example where the Sustainable Use category fails to maintain the proper services provided by coastal ecosystems.

\section{ACKNOWLEDGMENTS}

We would like to thank the Instituto Chico Mendes de Conservação da Biodiversidade (ICMBio) and the Fundação Florestal for the authorizations to conduct this research at the Cananeia-Iguape-Peruíbe Protection Area and Cardoso Island State Park, respectively. The study was supported by the Conselho Nacional de Desenvolvimento Científico e Tecnológico CNPq and the Fundação Grupo O Boticário.

\section{REFERENCES}

ALONGI, D. M. Mangrove forests: Resilience, protection from tsunamis, and responses to global climate change. Estuarine, Coastal and Shelf Science, v. 76, p. 1-13, 2008. https://doi.org/10.1016/j.ecss.2007.08.024.

ALONGI, D. M. The energetics of mangrove forests. Queensland: Springer Science, 2009.

BESERRA DE LIMA, N. G.; GALVANI, E. Mangrove Microclimate: A Case Study from Southeastern Brazil. Earth Interactions, v. 17, p. 1, 2013. https://doi.org/10.1175/2012EI000464.1

BRASIL. Lei $\mathbf{n}^{\circ}$ 9.985, DE 18 DE JULHO DE 2000. Disponível em: http://www.planalto.gov.br/ccivil_03/leis/19985.htm. Acesso em: 2 jun. 2021

BRASIL. Decreto $n^{\circ}$ 91.892, DE 06 DE NOVEMBRO de 1985. Disponível em: https://www2.camara.leg.br/legin/fed/decret/19801987/decreto-91892-6-novembro-1985-442098- publicacaooriginal-1-pe.html. Acesso em: 02 jun. 2021

BRASIL. Decreto $\mathbf{n}^{\circ} \mathbf{9 0 . 3 4 7}$, DE 23 DE OUTUBRO DE 1984. Disponível em http://www.planalto.gov.br/ccivil_03/atos/decretos/1 984/d90347.html. Acesso em: 02 jun. 2021

CENTRO DE PREVISÃO DE TEMPO E ESTUDOS CLIMÁTICOS. Portal com dados de previsão do tempo e estudos climáticos do Brasil. Disponível em: http://www.cptec.inpe.br. Acesso em: janeiro, 2012.

CINTRÓN, G.; SCHAEFFER-NOVELLI, Y. Introdución a la ecología del manglar. Montevideo: Oficina Regional de Ciência y Tecnologia de la Unesco para a América Latina y el Caribe, 1983. 109p.

CUNHA-LIGNON, M.; KAMPEL, M.; MENGHINI, R.P.; SCHAEFFER-NOVELLI, Y.; CINTRÓN, G.; DAHDOUH-GUEBAS, F. Mangrove Forests Submitted to Depositional Processes and Salinity Variation Investigated using satellite images and vegetation structure surveys. Journal of Coastal Research, SI 64, v. I, p. 344-348, 2011.

DUKE, N.C.; MEYNECKE, J.-0.; DITTMANN, A.M.; ELLISON, A.M.; AANGER, K.; BERGER, U.; CANNICCI, S.; DIELE, K.; EWEL, K.C.; FIELD, C.D.; KOEDAM, N.; LEE, S.Y.; MARCHAND, C.; NORDHAUS, I.; DAHDOUH-GUEBAS, F., A world without mangroves? Science, v. 317, p.41-42, 2007. https://doi.org/10.1126/science.317.5834.41b. ELLISON, J. Vulnerability assessment of mangroves to climate change and sea-level rise impacts. Wetlands Ecology and Management, v.23, p.115-137, 2015. https://doi.org/10.1007/s11273-014-9397-8.

GALVANI, E.; LIMA, N. G. B.; CUNHA-LIGNON, M. Análise microclimática de manguezais em Unidades de Conservação de Proteção Integral e de Uso Sustentável. In: PEREZ FILHO, A.; REIS, R. R.. (Orgs.). Os Desafios da Geografia Física na Fronteira do Conhecimento. Campinas: Instituto de Geociências - UNICAMP, v. 1 (ebook), 2017. https://doi.org/10.20396/sbgfa.v1i2017.2054

GIRI, C.; Ochieng, E; TIESZEN, L.L; DUKE, N. Status and distribution of mangrove forests of the world using earth observation satellite data. Global Ecology and Biogeography, v. 20, 2011. https://doi.org/10.1111/j.1466-8238.2010.00584.x.

KRAUSS, K.; DOYLE T.; DOYLE, T.; SWARZENSKI, C; FROM, A.; DAY, R.; CONNER, W. Water level observations in mangrove swamps during two hurricanes in Florida. Wetlands, v. 29, n. 1, 2009. https://doi.org/10.1672/07-232.1.

LACAMBRA, C.; SPENCER, T.; MOELLER, I. Tropical coastal ecosystems as coastal defences. ProAct Network, Unitec Kingdom, p. 1-22, 2008.

LIMA, N.G.B. DE, GALVANI, E.; CUNHA-LIGNON, M. Air temperature and canopy cover of impacted and conserved mangrove ecosystems: a study of a subtropical estuary in Brazil. Journal of Coastal Research, Special Issue, n. 65, 2013.

LIMA, NG. B.; GALVANI, E. Interação dos atributos climáticos nos manguezais do litoral sul de São Paulo e sua relação com os controles climáticos», 
Confins [Online], n. $\quad 36, \quad 2018$ https://doi.org/10.4000/confins. 14724 .

LUGO, A. E.; SNEDAKER, S. C. Properties of a mangrove forest in southern Florida. In: WALSH, G. E.; SNEDAKER, S. C.; TEAS, H. J. (Eds.). Proceedings of the International Symposium on Biology and Management of mangroves. Gainesville: Institute of Forest and Agricultural Scienses, University of Florida, v.1, p. 170-212, 1975.

LUGO, A. E.; MEDINA, E.; MCGINLEY, K. Issues and challenges of Mangrove conservation in the Anthropocene. Madera y Bosques, v. 20, $n$. especial11-38, https://doi.org/10.21829/myb.2014.200146.

MAGRIS, R.A.; BARRETO, R. Mapping and assessment of protection of mangrove habitats in Brazil. Pan-American Journal of Aquatic Sciences, v. 5, n. 4, p. 546-556, 2010.

MAHIQUES, M.M.; BURONE, L.; FIGUEIRA, R.C.L.; LAVENÉRE-WANDERLEY, A.A.O.; CAPELLARI, B.; ROGACHSKI, C.E.; BARROSO, C.P.; SANTOS, L.A.S.; CORDERO, L.M.; CUSSIOLI, M.C. Anthropogenic influences in a lagoonal environment: a multiproxy approach at the Valo Grande Mouth, Cananéia-Iguape System (SE Brazil). Brazilian Journal of Oceanography, v.57, n.4, p. 325-337, 2009. https://doi.org/10.1590/S1679-87592009000400007.

MCLVOR, A.; SPENCER, T.; MÖLLER, I.; SPALDING, M. Storm Surge Reduction by Mangroves. Natural Coastal Protection Series: Report 2. Cambridge Coastal Research Unit Working Paper 41. 2012.

MONTEIRO, C. A. F. A dinâmica climática e as chuvas no Estado de São Paulo: estudo geográfico sob forma de Atlas. São Paulo: Instituto de Geografia, Universidade de São Paulo, 1973. $130 \mathrm{p}$.

POOL, D. J., LUGO, A. E.; SNEDAKER, S. C. Litter production in mangrove forests of southern Florida and Puerto Rico.In: WALSH, G. E.; SNEDAKER, S. C.; TEAS, H. J. (Eds.). Proceedings of the International Symposium on Biology and Management of mangroves. Gainesville:
Institute of Forest and Agricultural Scienses, University of Florida, v.1, 1975.

SÃO PAULO. Decreto N. 40.319, DE 04 DE JULHO DE $1962 . \quad$ Disponível em: https://www.al.sp.gov.br/norma/94765. Acesso em: 2 jun. 2021

SCHAEFFER-NOVELLI, Y.; VALE, C.C.; CINTRÓN, G. Monitoramento do Ecossistema Manguezal: estrutura e características funcionais. In: TURRA, A.; DEDANAI, M. R. (Orgs.). Protocolos de campo para o monitoramento de habitats bentônicos costeiros. Rede de Monitoramento de Habitats Bentônicos Costeiros ReBentos. São Paulo - SP: IOUSP, p. 65 - 83, 2015. https://doi.org/10.7476/9788598729251.0005.

TARIFA，J. R. Unidades climáticas dos maciços litorâneos da Juréia-Itatins. In: MARQUES, O. A. V.; DULEBA (Orgs.). Estação Ecológica JuréiaItatins: Ambiente Físico, Flora e Fauna.São Paulo: Holos. p. 42 -50, 2004.

VALIELA, I.; BOWEN, J.L.; YORK, J.K. Mangrove Forests: One of the World's Threatened Major Tropical Environments. BioScience, v.51, p. 807 815, 2001. https://doi.org/10.1641/00063568(2001)051[0807:MFOOTW]2.0.CO;2.

WATSON, D.J. Comparative physiological studies in growth of field crops. I. variation in net assimilation rate and leaf area between species and varieties, and within and between yars. Annatomy and Botany. n. 11, p. 41-76, 1974. https://doi.org/10.1093/oxfordjournals.aob.a083148. ZHANG, K.; LIU, H.; LI, Y.; XU, H.; SHEN, J.; RHOME, J.; SMITH III, T. The role of mangroves in attenuating storm surges. Estuarine, Coastal and Shelf Science, v. 102 -103, p. 11 - 23, 2012. https://doi.org/10.1016/j.ecss.2012.02.021.

\section{AUTHORS' CONTRIBUTION}

Nádia Gilma Beserra de Lima, Marília CunhaLignon and Emerson Galvani were responsible for preparing, collecting and analyzing the data, as well as writing the article. 